\title{
Kentaro Wani, Neutrality in International Law. From the sixteenth century to 1945, Routledge, London-New York 2017, 206 ss.
}

Stała neutralność państwa wydaje się mieć czasy świetności za sobą. Znana i stosowana była już w starożytności (choć samo pojęcie neutralność weszło do obiegu naukowego dopiero w XVII-XVIII w.), ale rozkwit przeżywała między XVI a XIX stuleciem. Rozwinęły się przy tym dwie jej formy. Historycznie starsza była neutralność wojenna, a więc ogłaszana w czasie konfliktu zbrojnego państw trzecich. Później wykształciła się neutralność stała (wieczysta), deklarowana przez państwo jako zobowiązanie do niewikłania się w jakiekolwiek przyszłe konflikty. Z reguły neutralne były państwa słabe militarnie, chcące uniknąć zaangażowania w wojny pomiędzy silniejszymi podmiotami, np. Szwajcaria, Belgia czy Luksemburg w XIX w. albo Honduras w stuleciu XX. Po powstaniu Ligi Narodów, a zwłaszcza Organizacji Narodów Zjednoczonych, wydawało się, że instytucja neutralności zniknie z prawa międzynarodowego, tymczasem wobec ideologicznej rywalizacji zimnowojennych mocarstw zyskała nowe znaczenie. Po drugiej wojnie światowej taki status zdobyły Austria, Laos i Malta, a pod koniec wieku XX - Kambodża i Turkmenistan. Oznacza to, że skazywanie neutralności na niebyt jest obecnie przedwczesne, choć niewątpliwie wymaga ona rekonceptualizacji.

W naukach o prawie międzynarodowym publicznym i stosunkach międzynarodowych zagadnieniu neutralności nie poświęca się obecnie większej uwagi. Stała neutralność regulowana jest aktami prawa krajowego potwierdzonymi przez inne państwa, które ją uznają. Tworzy się tym samym wielokrotny węzeł obligacyjny, choć nie do końca jasne są prawa i obowiązki stron, a także odpowiedzialność podmiotu, który neutralność narusza. W przypadku neutralności wojennej wciąż obowiązują normy V i XIII konwencji haskich z 1907 r. - aktów obecnie przestarzałych i wymagających dogłębnej modyfikacji.

W związku powyższym zasadne wydaje się odnotowanie ukazania się na rynku wydawniczym monografii japońskiego badacza Kentaro Waniego pt. 'Neutralność w prawie międzynarodowym. Od szesnastego wieku do 1945 r.' Jest to studium ewolucji doktryny neutralności w jej pierwotnym, wojennym wydaniu. Porządkuje wiedzę z tego zakresu i pozwala na wyciągnięcie wniosków na temat skuteczności omawianej instytucji.

Recenzowana książka składa się ze wstępu, trzech rozdziałów, wniosków oraz bibliografii i ma strukturę chronologiczną. We wstępie autor zestawia 
wszystkie zbadane przez siebie i omówione na łamach pracy traktaty ustanawiające neutralność. Listę otwiera traktat pomiędzy Anglią i Kastylią z 1351 r., a za nim angielsko-portugalski z 1353 r. i francusko-burgundzki z 1522 r. Podstawowym celem prawa międzynarodowego jest według badacza uregulowanie używania siły w relacjach pomiędzy jego podmiotami, a neutralność to jedno z narzędzi ograniczających rozprzestrzenianie się konfliktów zbrojnych. Zarysowując powszechnie przyjęte tradycyjne, oparte na zwyczaju założenia neutralności, wskazuje on na brak prawa do pozostawania neutralnym (tj. brak ochrony statusu państwa neutralnego) oraz równe traktowanie wszystkich walczących państw przez podmiot neutralny.

W rozdziale pierwszym, ‘Źródła koncepcji neutralności: neutralność od szesnastego do osiemnastego wieku', omówione zostały okoliczności kształtowania się nowożytnej doktryny neutralności oraz jej zakres przedmiotowy. Analizując zebrane traktaty oraz ustalenia doktryny - w tym Hugona Grocjusza, Cornelisa van Bynkershoeka, Christiana Wolffa czy Emera de Vattela - Wani wskazuje, że ówczesną neutralność cechował wzajemny charakter zobowiązań podmiotu neutralnego i państwa tę neutralność uznającego. Oznaczało to, że państwo neutralne nie angażowało się w wojnę, a państwo uznające szanowało ten status i nie przyczyniało się do włączania neutralnego podmiotu w działania zbrojne. Jeżeli jednak dane państwo nie uznało neutralnego statusu innego podmiotu w formie traktatowej, to nie było zobligowane do jego poszanowania, co oznacza, że miało pełne prawo wypowiedzenia mu wojny. Następnie autor dogłębnie referuje ewolucję doktryny, wychodząc od koncepcji wojny sprawiedliwej (bellum justum), z zasady wykluczającej możliwość pozostania neutralnym, a więc i nieudzielenia pomocy państwu, które taką wojnę prowadziło. Odejście od tego stanowiska, będące aprecjacją instytucji neutralności, wiąże z myślą prawną van Bynkershoeka i jego następców. Słusznie łączy też wzrost znaczenia neutralności z rozwojem morskiej wymiany towarowej i początkiem epoki kolonialnej. Potrzeba uregulowania zagadnień handlu morskiego w czasie wojen doprowadziła do przyjęcia w XIII w. zbioru praw pt. Consolato del Mare. Wprowadzał on zasadę „wolny statek - wolny towar (za wyjątkiem kontrabandy)”, wyprzedzając tym samym właściwy rozwój doktryny neutralności państwa. Należy podkreślić, że Wani znakomicie wykorzystał teksty źródłowe autorstwa przywołanych wyżej badaczy.

Rozdział drugi, 'Prawo neutralności jako instytucja międzynarodowego prawa publicznego: 1793-1918', poświęcony jest nowoczesnemu etapowi rozwoju koncepcji neutralności. Pierwszym przykładem jest tu zadeklarowanie 
takiego statusu przez Stany Zjednoczone w okresie wojen napoleońskich, w wyniku czego obywatelom USA zakazywano pod groźbą sankcji jakiegokolwiek angażowania się w wojnę poprzez służbę, handel czy świadczenie innych usług. Następnie omówione zostały zbliżone regulacje wprowadzone do prawodawstwa brytyjskiego i francuskiego. Praktykę stosowania neutralności ilustruje kilka wybranych przykładów: internowanie w $1829 \mathrm{r}$. na Azorach grupy zmierzających do Brazylii brytyjskich ochotników przez królewską marynarkę, udział Amerykanów w rebelii kanadyjskiej w latach 1837-1838, konfliktach środkowoamerykańskich w latach 1853-1860 czy drugiej wojnie o niepodległość Kuby w latach 1895-1898. Szeroko naświetlony został też prawnomiędzynarodowy aspekt sprawy okrętu Alabama, zbudowanego na potrzeby wojny secesyjnej przez brytyjską stocznię. Oprócz tego Wani omawia ewolucję poglądów na temat możliwości faktycznego naruszania integralności terytorialnej państw neutralnych (doktryna zmierzała ku zakazowi innocent passage) oraz transportu osób chorych i rannych w toku działań zbrojnych. Dużo uwagi poświęca analizie V i XIII konwencji haskich z 1907 r., dotyczących praw i obowiązków państw neutralnych w czasie wojen lądowych i morskich. Omawia też w końcu zagadnienie krystalizacji teoretycznych podstaw do utrzymywania neutralności na przełomie XIX i XX w., odwołując się do ustaleń m.in. takich badaczy jak Lassa Oppenheim, Hersch Lauterpacht oraz prawników japońskich. Na gruncie doktryny nastąpiło wzmocnienie neutralności i podkreślenie obowiązku poszanowania jej przez państwa trzecie, niezależnie od formalnego uznania.

Ostatni rozdział książki, 'Rozwój prawa neutralności w okresie 1919-1945', poświęcony jest ewolucji doktryny w dość szczególnym okresie. Po powołaniu Ligi Narodów można było domniemywać, że neutralność przestanie istnieć, ponieważ wydawała się niezgodna $\mathrm{z}$ ustanawiającym tę organizację paktem. Co więcej, wiele państw postrzegało mechanizmy bezpieczeństwa zbiorowego za pewniejsze niż pozbawiony gwarancji status podmiotu neutralnego. Słusznie jednak zauważa Wani, że zasady działania Ligi Narodów nie wykluczały zachowania neutralności przez państwa członkowskie, ponieważ przyjęty przez organizację mechanizm sankcji nie miał charakteru obligatoryjnego. Z możliwości odmowy udziału w sankcjach nałożonych przez Ligę Narodów skorzystała m.in. Szwajcaria - po włoskiej agresji na Etiopię. Krótki renesans instytucji neutralności nastąpił tuż przed drugą wojną światową, gdy okazało się, że mechanizmy bezpieczeństwa zbiorowego nie będą skutecznym narzędziem zabezpieczającym przed wybuchem konfliktu. Autor wskazuje przy tym na dalece niedoskonałą praktykę neutralności Norwegii, Belgii i Holandii 
w czasie wojny. Oddzielnie omawia też okoliczności wprowadzenia i zaniechania neutralności przez Stany Zjednoczone. Na koniec wreszcie, referując krótko zmiany w doktrynie po 1945 r., zwraca uwagę na trend ku deprecjonowaniu neutralności państw w prawie międzynarodowym.

Podsumowując, recenzowana praca stanowi cenne studium ewolucji doktryny i praktyki instytucji neutralności wojennej. Choć problematyka ta nie leży obecnie w centrum zainteresowania badaczy, to niewątpliwie neutralność ostatecznie nie zniknęła z myśli prawnomiędzynarodowej oraz praktyki stosunków międzynarodowych i wciąż ma określony potencjał wpływu na stan bezpieczeństwa.

Rafat Czachor 